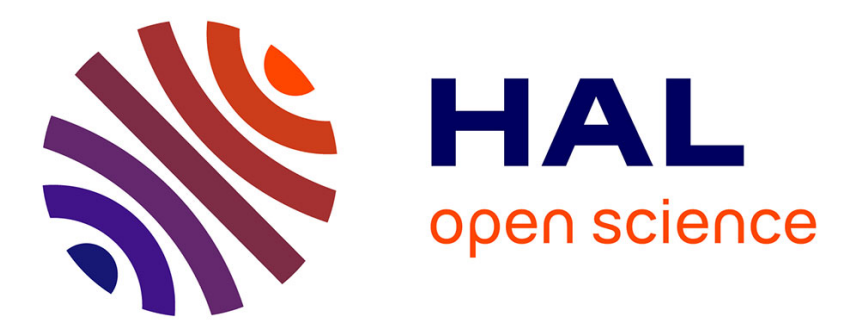

\title{
Benefits of second-look laparoscopy in the management of pelvic inflammatory disease
}

\author{
Anne Sophie Gremeau, Anais Girard, Celine Lambert, Pauline Chauvet, \\ Nicolas Bourdel, Michel Canis, Jean Luc Pouly
}

\section{- To cite this version:}

Anne Sophie Gremeau, Anais Girard, Celine Lambert, Pauline Chauvet, Nicolas Bourdel, et al.. Benefits of second-look laparoscopy in the management of pelvic inflammatory disease. Journal of Gynecology Obstetrics and Human Reproduction, 2019, 48, pp.413 - 417. 10.1016/j.jogoh.2019.03.020 . hal-03484954

\section{HAL Id: hal-03484954 \\ https://hal.science/hal-03484954}

Submitted on 20 Dec 2021

HAL is a multi-disciplinary open access archive for the deposit and dissemination of scientific research documents, whether they are published or not. The documents may come from teaching and research institutions in France or abroad, or from public or private research centers.
L'archive ouverte pluridisciplinaire HAL, est destinée au dépôt et à la diffusion de documents scientifiques de niveau recherche, publiés ou non, émanant des établissements d'enseignement et de recherche français ou étrangers, des laboratoires publics ou privés.

\section{다)(1) $(5$}

Distributed under a Creative Commons Attribution - NonCommercial| 4.0 International 


\title{
Benefits of second-look laparoscopy in the management of pelvic inflammatory disease
}

\author{
AUTHORS \\ GREMEAU Anne Sophie, MD \\ Department of Gynecology, University Hospital, Clermont-Ferrand, France \\ GIRARD Anais, MD, \\ Department of Gynecology, University Hospital, Clermont-Ferrand, France \\ LAMBERT Celine \\ Biostatistics Unit (DRCI), University Hospital, Clermont-Ferrand, France \\ CHAUVET Pauline, MD \\ Department of Gynecology, University Hospital, Clermont-Ferrand, France \\ BOURDEL Nicolas, PHD \\ Department of Gynecology, University Hospital, Clermont-Ferrand, France \\ CANIS Michel, PHD \\ Department of Gynecology, University Hospital, Clermont-Ferrand, France \\ POULY Jean Luc, PHD \\ Department of Gynecology, University Hospital, Clermont-Ferrand, France
}

Correponding author :

GREMEAU Anne Sophie, MD asgremeau@chu-clermontferrand.fr CHU Clermont-Ferrand, Department of gynecology 1 place Lucie et Raymond AUBRAC, 63100 Clermont Ferrand Cedex 1 , France $+0033473755042$ 


\section{INTRODUCTION}

Pelvic inflammatory disease (PID) involves deep and severe visceral infections due

4 to bacteria from the endometrium attaining the fallopian tubes following sexually transmitted

5 infection (STI), an endo-uterine maneuver or due to neighboring infection. (1). In France,

6200,000 new cases of PID are recorded per year, with 55\% of patients aged under 25. These

7 young women are of childbearing age and have a high risk of complications such as chronic

8 pelvic pain, recurrence, ectopic pregnancy and infertility sequelae (2). Success of PID

9 treatment may not lead to anatomical ad-integrum restitution, and only intra-uterine 10 pregnancy being the best indicator of complete healing.

Treatment involves antibiotics at the acute phase and surgical management may be

necessary when imaging reveal tubo-ovarian abscess, in cases of poor clinical tolerance,

resistance to medical treatment or unconfirmed diagnosis as specified in French $(3,4)$,

European (5) and American (6) recommendations. Surgical management in the acute phase is drainage of the abcess and should be done by laparoscopy or by puncture under vaginal guidance. Using surgical classification, initial management by laparoscopy, makes it possible

to determine 3 stages of salpingitis (7) At stage 1 (catarrhal) tubes reveal congestion and hyperemia, stage 2 (parenchymatous) is characterised by increased inflammation levels, and stage 3 (severe salpingitis) by the presence a tubo-ovarian abscess. Second-look laparascopy (SLL) are only reserved for cases of infertility or chronic pelvic pain.

These recommendations favoring medical treatment are based on conclusions from the PEACH study $(8,9)$ which reported that following medical treatment only, $57 \%$ of patients conceived and $42 \%$ delivered. These encouraging results brought about changes in practice and notably a considerably reduced use of first surgery and of SLL, even though the study 
only included patients with moderate PID and excluded "tubo-ovarian abscess and surgical abdomens". Furthermore the study reported unacceptably high results for infertility (19\%) and subsequent pelvic pain (42\%) for patients treated for moderate levels of PID. A comparison of these results with those obtained from systematic surgical management and particularly for acute cases, remains to be carried out. Lastly, no further treatment was proposed to allow evaluation of fertility or reduce risk of complications.

Previously both Bouedec et al (10) and Raiga et al (11) had presented results in favor SLL for assessment and restoring of patient fertility. Notably the possibility of obtaining a prognosis concerning fertility, based on the Mage score (grade 1 to 4 ) obtained from tubal evaluation (12) and an adhesion score using the American Fertility Society classification (AFS) (13). These scores are described in table 1. This present study aims to evaluate the results and benefits of SLL in cases of PID and to evaluate risk factors that lead to severe complications concerning fertility and which indicate the need for SLL.

(1)

\section{Materials and Methods}

This unicentric retrospective study was carried out at Clermont-Ferrand University Hospital Center over a 5-year period from January 1, 2010 to December 31, 2014. Inclusion criteria concerned all patients who had undergone SLL due to PID initially treated either medically or surgically. A total of 188 patients had received treatment for PID and benefited from a hospital stay (outpatients were not included). Of these, 96 were excluded because they didn’t have SLL (age> 43 years, associated endometriosis, immediate management for assisted reproductive techniques (ART) and patient refusal) and 16 had SLL but incomplete data (missing data or more than 10 years between initial PID and SLL). A total of 76 patients were finally included as described in the Flow chart (table 2). 
Extensive data collection was carried out to include patient characteristics, clinical

and para-clinical characteristics of salpingitis, initial medical and surgical management data, indications and SLL details, and information concerning long-term follow-up notably patient fertility. Two scores relating to fertility were obtained for each surgical intervention: the

Mage score (grade 1 to 4 ) for tubal assessment and the AFS classification concerning adhesions (score 0 to 3 ). AFS scores 0 and 1 were included in the analyses and so provided increased statistical power.

60

Statistical analysis was performed using Stata software (version 13, StataCorp,

62

\section{RESULTS}


Our study included 76 patients who underwent SLL post-PID, with an average of 15

77 per years. General patient characteristics and details of the initial infection episode are summarized in Table 3. When chlamydiae trachomatis has been requested IgG serology was positive in $72,9 \%$, and PCR in $39,5 \%$. Other germs were streptococcus, E coli, Neisseiria gonorrhae ans staphyloccoccus aureus. Antibiotic therapy was administered in $100 \%$ of cases. Before the french recommandation differents bi ou tri-antibiothérapy were used (amoxicillin and clavulanic acid, levofloxacin, metronidazol and/or ofloxacin). Since 2012 association of Metronidazol and ofloxacin were the reference. Initial surgical management was performed in $57(75 \%)$ patients, the indications were the presence of an abscess confirmed by imaging, uncertain diagnosis and unfavorable clinical evolution in $(26.3 \%)$. During initial surgery, $57.9 \%$ of patients were found to have stage 3 salpingitis. Procedure during initial surgery was adhesiolysis in 93\%, salpingectomy in 5.3\%, abcess drainage including salpingotomy in $43.9 \%$. Dye tests werent't performed during initial surgery. (1)

Indication of the SLL were pelvic pain (21.1\%), hydrosalpinx (18.4\%) and others were offered routinely (60.5\%). During SLL, $78.9 \%$ of patients underwent adhesiolysis and $42.1 \%$ tube-related treatment. (19,7\% of salpingectomy and $22,4 \%$ of neostomy or fimbrioplasty. The median time between initial surgery and SLL was 3.5 months $[3 ; 5]$. An adhesion score was recorded for all patients and the Mage score obtained for 72 patients. 63 patients received long-term follow-up and were contacted by phone, of whom 30 patients (34\%) expressed a desire to conceive. We had 23 pregnancies and outcomes were as follows: 16 live births (69.6\%), 2 ectopic pregnancy (8.7\%), 2 early miscarriage (8.7\%) and 3 abortions (13\%). Only 5 patients benefited from ART, and two pregnancies were due to IVF. The infertility rate was $23.3 \%$. 
for stages 1 and $2(\mathrm{p}=0.001)$. During SLL, more patients in this group received a high revealed that stage 3 patients are 8.2 times more likely to have higher adhesion levels than stage 1 or 2 patients $(\mathrm{OR}[95 \% \mathrm{CI}]=8.2[2.2 ; 30.5], \mathrm{p}=0.02)$.

Finally, analysis of the relationship between fertility and Mage and adherence scores at SLL was performed by comparing patients who conceived after surgery with those who did not. A total of 30 patients with a childbearing project were selected and included 23 who conceived. Results obtained during SLL allowed the authors to establish a relationship between the pregnancies obtained, their characteristics and fertility scores. Mage scores of 1 or 2 were found to be associated with a higher pregnancy and birth rate), although this result was not significant. Mage score of 4 was significantly associated with a higher ectopic pregnancy rate. These results are shown in Table 5.

\section{DISCUSSION}

The Kreisel study conducted in the US found a 4.4\% prevalence of PID in sexually

122 active women, this report highlight the magnitude of this public health issue which impacts 123 young women of childbearing age (14). As explained in the introduction, since 2012 as a 124 result of the PEACH study (9), guidelines no longer recommend systematic surgical 125 management, and medical treatment by antibiotics is the first-line therapy (3-6). But, the 
conclusions were uniquely based on cases of moderate PID for which complication rates were still high i.e. $19 \%$ infertility and $42 \%$ chronic pelvic pain. At least, first line antibiotherapy have never shown their efficacity on fertility after PID especially in severe forms (10).

Studies investigating initial surgical management in PID, include the Chayachinda cohort conducted from 2004 to 2011, which reported a low surgical rate of $12.8 \%$ for patients with tubo-ovarian abscess (TOA) (15). Kontoravdis et al, reported a $22.8 \%$ rate of surgery for patients with acute pain linked to salpingitis (16). In our study a higher rate of patients underwent primary laparoscopy (75\%), of whom more than half had TOA, our results shows that we probably made two much initial surgery, but the evaluation of the SLL, confirmed that severe PID are more at risk of potential complications like adhesions and tubal infertility and ectopic pregnancies. This is confirmed by the recent French recommendation which support the drainage of tubo-ovarian abcess. This drainage should be realized by vaginal puncture under ultrasound guidance or by laparoscopy, as quickly as possible. Our results, in agreement with this guidelines showed that initial surgery shouldn't by systematic except in severe form with TOA $(3,4)$.

Up to date, in cases of abscess $>3 \mathrm{~cm}$, present guidelines advocate drainage by transvaginal route, due to the feasibility and reproducibility of this technique. Granberg et al, in a review of the literature reported a success rate in $77-100 \%$ of patients (17) and the French Vermersch study a success rate of 94\% (18). Gjelland, reported complete healing from infection in $93.4 \%$ of patients (19). In a second study, published in $2012,52.8 \%$ of patients who underwent draining and wished to become pregnant, conceived (20). But patients "who had undergone surgery (after drainage) that made future pregnancy not recommandable" were excluded. Only 38 "good cases" were included and finally only 22 give birth $(52 \%), \ldots$ So if vaginal drainage, is efficient on the treatment of the acute phase of PID, we have very poor 
data about fertility. Moreover, no study to our knowledge has compared efficacy in terms of clinical efficiency and fertility of vaginal vs laparoscopic drainage, data are still missing. Infertility rates following PID can be high, such as in the USA where rates may vary from $21.3 \%$ - 55.6\% (9). In our study we found a 37,5\% infertility rate, with only 15 out of 24 women desiring to conceive, who delivered. Assessment of fertility in post-PID patients is frequently difficult, requiring long-term follow-up for collection of data on pregnancy and acute episode outcomes. SLL therefore provides a key opportunity to collect validated fertility scores, specifically MAGE and AFS adhesion scores as previously described. Accordingly Mage et al (1987) highlighted the relationship between the salpingitis stage, second-look laparoscopy and fertility prognosis, and reported a pregnancy rate that ranged from $58.3 \%$ for stage I to $0 \%$ for stage IV (12). These results were confirmed by following studies as Le bouedec (1991), Raiga (1996) Gerber et al (1996) who performed control laparoscopies and found high rates of adhesions and tubal occlusion $(10,11,21)$. In a recent retrospective study Chayachinda et al. (2017), used multivariate analysis to show that the presence of a tuboovarian abscess is a negative predictor of delivery rate (15). Finally, Audebert et al (2014) reported on a more than 10-year follow-up of 434 patients who underwent neosalpingostomy, and consequently advised performing tubal repair in patients selected on the basis of adhesion stage and tubal score. (22). All these results confirmed the interest of a SLL after TOA, and the treatment of the adhesions or the tubal defects. But it's also highlight that no studies and no data are available about fertility post vaginal drainage of TOA, because all SLL were made following laparoscopic intial treatment.

Our study revealed an association between initial infection, secondary adhesions, Mage score and patient fertility. Thus patients with stage 3 PID are 8 times more likely to present with a high level of adhesions than stage 1 or 2 patients $(\mathrm{OR}[95 \% \mathrm{CI}]=8.2[2.2$; 30.5], $\mathrm{p}=0.02$ ). Mage scores of 1 or 2 are associated with higher pregnancy and delivery 
rates than Mage of 3 or $4(\mathrm{p}=\mathrm{ns})$, and Mage score of 4 are associated with highly ectopic

176 pregnancies $(\mathrm{p}=0.03)$. These figures correlate with the severity of the initial infection. SLL

177 should therefore be recommended in women who have presented with tubo-ovarian abscess.

178 Some theories estimates that's more the initial infection is severe, more the initial treatment of

179 the tube and its repair in case of damage is quick, more the benefits on the fertility is 180 important $(23,24)$. We also knows that the infected tubes are also more susceptible to 181 blockage, which if unresolved may lead to hydrosalpinx, a condition resulting in reduced 182 results in IVF as demonstrated by Strandell (25). This provides further evidence in support of 183 carrying out second look laparoscopy in patients wishing to conceive; usually performed by 184 infertility surgeons, experienced in tubal surgery.

The main limitation of our study concerns its retrospective nature and corresponding 186 issues linked to data collection and reliability. But, our study is the first since the publishing of CNGOF guidelines, to report on fertility following SLL and thus highlight patient groups susceptible to benefit from this technique. For patients, the outcomes of upmost importance is giving birth to a healthy child. Long-term follow-up data is also necessary for assessment of 190 risk of recurrences and pelvic pain. A prospective randomized study about SLL after tubo191 ovarian abcess is actually in progress in our center (ClinicalTrials.gov Identifier: NCT03166982).

\section{CONCLUSION}

195 Over recent years there has been a sharp increase in the incidence of PID in women 196 of childbearing age. Recents guidelines about PID endorse the use of dual-antibiotic therapy, 197 reserving first-line surgery for complicated severe cases and second look laparoscopy (SLL) 198 for selected patients with pelvic pain. Our study, revealed an association between PID initial 199 stages, adhesions, tube- related procedures and patient fertility. While SLL was shown to have 
little impact on the preservation of fertility in cases of mild to moderate PID, our results find

an interest of recommending SLL in women desirous pregnancy and who had a tubo-ovarian

abscess at the initial stage. Prospective studies should be done to confirm these results.

\section{$\underline{\text { References }}$}

1- Mitchell C, Prabhu M. Pelvic inflammatory disease: current concepts in pathogenesis, diagnosis and treatment. Infect Dis Clin North Am. 2013 Dec;27(4):793-809.

2- InVS. Bulletins des reseaux de surveillance des ISTs (internet). 2015. Available from : http://invs.santepubliquefrance.fr

3- Graesslin O. Pelvic inflammatory diseases: guidelines for clinical practice - method and organization.J Gynecol Obstet Biol Reprod (Paris). 2012 Dec;41(8):833-4

4- Brun JL, Graesslin O, Fauconnier A, Verdon R, Agostini A, Bourret et al; Collège National des Gynécologues Obstétriciens Français Updated French guidelines for diagnosis and management of pelvic inflammatory disease. Int J Gynaecol Obstet. 2016 Aug;134(2):121-5.

5- Ross J, Judlin P, Jensen J; International Union against sexually transmitted infections. 2012 European guideline for the management of pelvic inflammatory disease. Int $\mathbf{J}$ STD AIDS. 2014 Jan;25(1):1-7.

6- Haulk L. CDC Releases 2015 guidelines on the treatment of sexually transmitted disease. Am Fam Physician, 2016 Jan 2015;93(2):144-54.

7- Mage $\mathrm{G}$ et al. Chirurgie coelioscopique en gynécologie. Elsevier Masson, 2eme édition 2015;64-71.

8- Trent M, Bass D, Ness RB, Haggerty C. Recurrent PID, subsequent STI, and reproductive health outcomes: findings from the PID evaluation and clinical health (PEACH) study. Sex Transm Dis. 2011 Sep;38(9):879-81.

9- Ness RB, Soper DE, Holley RL, Peipert J, Randall H, Sweet RL, et al. Effectiveness of inpatient and outpatient treatment strategies for women with pelvic inflammatory disease: results from the Pelvic Inflammatory Disease Evaluation and Clinical Health (PEACH) Randomized Trial. Am J Obstet Gynecol. 2002 May;186(5):929-37.

10- Le Bouëdec G, Pouly JL, Canis M, Wattiez A, Abbas B, Mage G, Bruhat MA Acute salpingitis. Celioscopy before and after treatment: 110 cases].. J Gynecol Obstet Biol Reprod (Paris). 1991;20(5):680-4.

11- Raiga J, Canis M, Le Bouëdec G, Glowaczower E, Pouly JL, Mage G, Bruhat MA. Laparoscopic management of adnexal abscesses: consequences for fertility. Fertil Steril. 1996 Nov;66(5):712-7.

12- Mage G, Pouly JL, de Jolinière JB, Chabrand S, Riouallon A, Bruhat MA. A preoperative classification to predict the intrauterine and ectopic pregnancy rates after distal tubal microsurgery. Fertil Steril. 1986 Nov;46(5):807-10.

13- The American Fertility Society classifications of adnexal adhesions, distal tubal occlusion, tubal occlusion secondary to tubal ligation, tubal pregnancies, müllerian anomalies and intrauterine adhesions. Fertil Steril. 1988 Jun;49(6):944-55.

14- Kreisel K, Torrone E, Bernstein K, Hong J, Gorwitz R. Prevalence of Pelvic Inflammatory Disease in Sexually Experienced Women of Reproductive Age - United States, 2013-2014. MMWR Morb Mortal Wkly Rep. 2017 Jan 27;66(3):80-83. 
15- Chayachinda C, Rekhawasin T. Reproductive outcomes of patients being hospitalised with pelvic inflammatory disease. J Obstet Gynaecol. 2017 Feb; 37 (2):228-232.

16- Kontoravdis A, Chryssikopoulos A, Hassiakos D, Liapis A, Zourlas PA. The diagnostic value of laparoscopy in 2365 patients with acute and chronic pelvic pain. Int J Gynaecol Obstet. 1996 Mar;52(3):243-8.

17- Granberg S, Gjelland K, Ekerhovd E. The management of pelvic abscess. Best Pract Res Clin Obstet Gynaecol 2009; 23 (5):667-78.

18- Vermersch C, Dessein R, Lucot JP, Rubod C, Cosson M, Giraudet G. Tubo-ovarian abscesses treatment: Faisability and results of trans-vaginal ultrasound-guided aspiration. J Gynecol Obstet Biol Reprod 2016 Mar;45(3):243-8

19- Gjelland K, Ekerhovd E, Granberg S. Transvaginal ultrasound-guided aspiration for treatment of tubo-ovarian abscess: a study of 302 cases. Am J Obstet Gynecol. 2005 Oct;193(4):1323-30.

20- Gjelland K, Granberg S, Kiserud T, Wentzel-Larsen T, Ekerhovd E. Pregnancies following ultrasound-guided drainage of tubo-ovarian abscess. Fertil Steril. 2012 Jul;98(1):136-40.

21- Gerber B, Krause A. A study of second-look laparoscopy after acute salpingitis. Arch Gynecol Obstet. 1996; 258 (4):193-200.

22- Audebert A, Pouly JL, Bonifacie B, Yazbeck C. Laparoscopic surgery for distal tubal occlusions: lessons learned from a historical series of 434 cases. Fertil Steril. 2014 Oct;102(4):1203-8.

23- Jacobson L, Weström L. Objectivized diagnosis of acute pelvic inflammatory disease. Diagnostic and prognostic value of routine laparoscopy. Am J Obstet Gynecol. 1969 Dec 1;105(7):1088-98.

24- Weström L. Incidence, prevalence, and trends of acute pelvic inflammatory disease and its consequences in industrialized countries. Am J Obstet Gynecol. 1980 Dec 1;138(7 Pt 2):880-92.

25- Strandell A. The influence of hydrosalpinx on IVF and embryo transfer. A review. Human Reprod Update. 2000 Jul-Aug;6(4):387-95 
Table 1: AFS Adhesion score and MAGE score

\section{Mage Score}

\begin{tabular}{|l|l|l|l|l|}
\hline \multicolumn{1}{|c|}{ Score } & \multicolumn{1}{|c|}{$\mathbf{0}$} & \multicolumn{1}{c|}{$\mathbf{2}$} & \multicolumn{1}{c|}{$\mathbf{5}$} & 10 \\
\hline Permeability & & Phimosis & Hydro-salpinx & \\
\hline Tubal mucosa & $\begin{array}{l}\text { Mucosal folds } \\
\text { maintained }\end{array}$ & & Folds diminished & $\begin{array}{l}\text { No folds ou } \\
\text { synechia }\end{array}$ \\
\hline Tubal wall & Normal & & Thin & Thick \\
\hline
\end{tabular}

Stage 1 (2-5) ; stage 2 (6-10); stage 3 (11-15); stage 4 (>15)

AFS adhesion Score

\begin{tabular}{|l|ll|c|c|c|}
\hline \hline & ADHESIONS & $<1 / 3$ Enclosure & \multicolumn{1}{l|}{$\begin{array}{l}\text { 1/3-2/3 } \\
\text { Enclosure }\end{array}$} & $>2 / 3$ Enclosure \\
\hline OVARY & R & Filmy & 1 & 2 & 4 \\
& & Dense & 4 & 8 & 16 \\
& L & Filmy & 1 & 2 & 4 \\
& & Dense & 4 & 8 & 16 \\
\hline TUBE & R & Filmy & 1 & 2 & 4 \\
& & Dense & $4^{*}$ & $8^{*}$ & 16 \\
& L & Filmy & 1 & 2 & 16 \\
& & Dense & $4^{*}$ & $8^{*}$ & 16 \\
\hline
\end{tabular}

*If the fimbria end of the fallopian tube is completely enclosed, change the point assignment to 16

Stage I : no adhesions, Stage II : mild adhesions (1-6) ; stage III : moderate adhesions (7-15); stage IV : severe adhesions (>15) 
Table 2 : Flow chart of the study




Table 3: Patient and PID characteristics, treatment and second-look laparoscopy

\begin{tabular}{|c|c|}
\hline & Total $(n=76)$ \\
\hline $\begin{array}{l}\text { Age (years) } \\
\text { Age }>37 \text { years }\end{array}$ & $\begin{array}{r}27.6 \pm 8.5 \\
14(18.4)\end{array}$ \\
\hline $\begin{array}{l}\text { Medical history } \\
\text { Abortion } \\
\text { Sexually transmitted infections } \\
\text { Abdominal-pelvic surgery } \\
\text { Intrauterine device } \\
\text { Smoking }\end{array}$ & $\begin{array}{r}26(34.2) \\
7(9.2) \\
26(34.2) \\
22(28.9) \\
43 / 64(67.2)\end{array}$ \\
\hline $\begin{array}{l}\text { Symptoms } \\
\text { Pelvic pain } \\
\text { Defense } \\
\text { Leucorrhoea } \\
\text { Fever }>38^{\circ} \mathrm{C} \\
\text { Severe sepsis }\end{array}$ & $\begin{array}{r}76(100.0) \\
21(27.6) \\
40(52.6) \\
31(40.8) \\
2(2.6)\end{array}$ \\
\hline $\begin{array}{l}\text { Paraclinical tests } \\
\text { Normal echography } \\
\text { Abscess } \\
\text { Size of abscess (mm) } \\
\text { White blood cells }(\mathrm{g} / \mathrm{l}) \\
\text { C-reactive protein }(\mathrm{mg} / \mathrm{l}) \\
\text { Chlamydia serology IgG + } \\
\text { Chlamydia PCR positive }\end{array}$ & $\begin{array}{r}9 / 72(12.5) \\
34 / 72(47.2) \\
43.5 \pm 14.5 \\
13.3[9.4 ; 17.8] \\
92.6[43.9 ; 171.0] \\
35 / 48(72.9) \\
15 / 38(39.5)\end{array}$ \\
\hline $\begin{array}{l}\text { Initial treatment } \\
\text { Antibiotic treatment }\end{array}$ & $76(100.0)$ \\
\hline $\begin{array}{l}\text { Surgical treatment } \\
\text { Adhesiolysis } \\
\text { Salpingectomy } \\
\text { Drainage }\end{array}$ & $\begin{array}{r}57(75.0) \\
53 / 57(93) \\
3 / 57(5.3) \\
25 / 57(43,9)\end{array}$ \\
\hline $\begin{array}{l}\text { PID stage } \\
1 \\
2 \\
3 \\
\end{array}$ & $\begin{array}{r}6 / 57(10.5) \\
18 / 57(31.6) \\
33 / 57(57.9)\end{array}$ \\
\hline $\begin{array}{l}\text { Second-look laparoscopy } \\
\text { Indication } \\
\text { Systematic } \\
\text { Pelvic pain } \\
\text { Imagery } \\
\text { Length of surgery (minutes) }\end{array}$ & $\begin{array}{r}46(60.5) \\
16(21.1) \\
14(18.4) \\
37[30 ; 51]\end{array}$ \\
\hline $\begin{array}{l}\text { Adhesions score (AFS) } \\
\text { Stage I-II (none or small) } \\
\text { Stage III (moderate) } \\
\text { Perihepatitis (Fitz Hugh Curtis) Stage IV (severe) }\end{array}$ & $\begin{array}{r}18(23.7) \\
25(32.9) \\
33(43.4) \\
8(10.5)\end{array}$ \\
\hline $\begin{array}{l}\text { Tubal score (MAGE) } \\
\text { Stage } 1 \\
\text { Stage } 2 \\
\text { Stage } 3 \\
\text { Stage } 4\end{array}$ & $\begin{array}{r}52 / 72(72.2) \\
6 / 72(8.3) \\
5 / 72(7.0) \\
9 / 72(12.5)\end{array}$ \\
\hline $\begin{array}{l}\text { Adhesiolysis } \\
\text { Salpingectomy } \\
\text { Neostomy or fimbrioplasty }\end{array}$ & $\begin{array}{l}60(78.9) \\
15(19.7) \\
17(22.4)\end{array}$ \\
\hline
\end{tabular}

Data are presented as frequencies (associated percentage), as mean \pm standard deviation, or as median [interquartile range]. 


\begin{tabular}{|c|c|c|c|}
\hline & $\begin{array}{r}\text { Stage } 1 \text { or } 2 \\
(n=24)\end{array}$ & $\begin{array}{r}\text { Stage } 3 \\
(n=33)\end{array}$ & p-value \\
\hline \multicolumn{4}{|l|}{ Paraclinical tests } \\
\hline Normal echography & $2 / 21(9.5)$ & $1 / 32(3.1)$ & 0.34 \\
\hline Abscess & $6 / 21(28.6)$ & $25 / 32(78.1)$ & $<0.001$ \\
\hline White blood cells $(\mathrm{g} / \mathrm{l})$ & $10.2[7.9 ; 15.3]$ & $15.6[12.9 ; 19.2]$ & 0.004 \\
\hline C-reactive protein (mg/l) & $90.2[39.8 ; 132.0]$ & $91.7[37.0 ; 188.0]$ & 0.42 \\
\hline Chlamydia serology IgG & $11 / 14(78.6)$ & $16 / 26(61.5)$ & 0.32 \\
\hline PCR positive chlamydia & $8 / 13(61.5)$ & 3/14 (21.4) & 0.03 \\
\hline \multicolumn{4}{|l|}{ Initial surgery } \\
\hline Severe adhesions (stage IV AFS) & $6(25.0)$ & $24(72.7)$ & $<0.001$ \\
\hline Salpingectomy & $0(0)$ & $3(9.1)$ & 0.26 \\
\hline Abscess drainage & $3(12.5)$ & $22(66.7)$ & $<0.001$ \\
\hline \multicolumn{4}{|l|}{ Second-look laparoscopy } \\
\hline $\begin{array}{l}\text { Adhesions score (AFS) } \\
\text { Stage I-II (none or small) } \\
\text { Stage III (moderate) } \\
\text { Stage IV (severe) }\end{array}$ & $\begin{array}{r}6(25.0) \\
12(50.0) \\
6(25.0)\end{array}$ & $\begin{array}{r}4(12.1) \\
8(24.3) \\
21(63.6)\end{array}$ & 0.02 \\
\hline $\begin{array}{c}\text { Tubal score (MAGE) } \\
\text { Stage } 1 \\
\text { Stage } 2 \\
\text { Stage } 3 \\
\text { Stage } 4\end{array}$ & $\begin{array}{r}21 / 23(91.3) \\
0 / 23(0.0) \\
2 / 23(8.7) \\
0 / 23(0.0)\end{array}$ & $\begin{array}{r}16(48.5) \\
6(18.2) \\
2(6.0) \\
9(27.3)\end{array}$ & $<0.001$ \\
\hline $\begin{array}{l}\text { Adhesiolysis } \\
\text { Salpingectomy } \\
\text { Neostomy or fimbrioplasty }\end{array}$ & $\begin{array}{r}20(83.3) \\
1(4.2) \\
6(25)\end{array}$ & $\begin{array}{l}29(87.9) \\
10(30.3) \\
10(30.3)\end{array}$ & $\begin{array}{l}0.71 \\
0.02 \\
0.66\end{array}$ \\
\hline
\end{tabular}

Data are presented as frequencies (associated percentage), as mean \pm standard deviation, or as median [interquartile range]. 
Table 5: Fertility according to tubal and adhesion score during second-look laparoscopy $(\mathbf{n}=\mathbf{3 0})$

\begin{tabular}{lrrrr}
\hline & $\mathbf{n}$ & Pregnancies & $\begin{array}{r}\text { Ectopic } \\
\text { pregnancies }\end{array}$ & Deliveries \\
\hline Adhesions score (AFS) & & & & \\
$\quad$ Stage I-II (none or small) & 7 & $5 / 7(71.4)$ & $0 / 7(0.0)$ & $4 / 7(57.1)$ \\
$\quad$ Stage III (moderate) & 9 & $8 / 9(88.9)$ & $0 / 9(0.0)$ & $7 / 9(77.8)$ \\
Stage IV (severe) & 14 & $10 / 14(71.4)$ & $2 / 14(14.3)$ & $5 / 14(35.7)$ \\
$\quad$-value & & 0.64 & 0.49 & 0.13 \\
Tubal score (MAGE) & & & & \\
Stage 1 & 24 & $19 / 24(79.2)$ & $0 / 24(0.0)$ & $15 / 24(62.5)$ \\
Stage 2 & 4 & $2 / 4(50.0)$ & $1 / 4(25.0)$ & $1 / 4(25.0)$ \\
Stage 3 & 0 & 0 & 0 & 0 \\
Stage 4 & 2 & $2 / 2(100.0)$ & $1 / 2(50.0)$ & $0 / 2(0.0)$ \\
p-value & & 0.27 & 0.03 & 0.14 \\
\hline
\end{tabular}

Data are presented as frequencies (associated percentage). 